\title{
Bladder Cancer: Epidemiological, Clinical and Histopathological Aspects at the University Hospital Point G, Mali
}

\author{
Honoré Jean Gabriel Berthé1,2, Dramane Cissé1,3*, Moussa Salifou Diallo1,4, Amadou Kassogué1,4, \\ Alkadri Diarra1,5, Mamadou Tidiani Coulibaly 1,6, Mamadou Lamine Diakité1,2, \\ Modibo Coulibaly ${ }^{1,3}$, Mory Koné1,3
}

\author{
${ }^{1}$ Université des Sciences des Techniques et des Technologies de Bamako, Bamako, Mali \\ ${ }^{2} \mathrm{CHU}$ du Point G Bamako, Bamako, Mali \\ ${ }^{3}$ Hôpital Sominé DOLO de Mopti, Mopti, Mali \\ ${ }^{4} \mathrm{CHU}$ Kati, Kati, Mali \\ ${ }^{5} \mathrm{CHU}$ Luxembourg, Bamako, Mali \\ ${ }^{6} \mathrm{CHU}$ Gabriel TOURE Bamako, Bamako, Mali \\ Email: berthonore@hotmail.com, *djennecisse@yahoo.fr, mousalifon@gmail.com, amadouenet@yahoo.fr, \\ Bamako.dralkadri@yahoo.fr, mamadoutc@yahoo.fr, diakite.mlamine@hotmail.fr, modibocoulibaly@yahoo.com, \\ Konemory@gmail.com
}

How to cite this paper: Berthé, H.J.G., Cissé, D., Diallo, M.S., Kassogué, A., Diarra, A., Coulibaly, M.T., Diakité, M.L., Coulibaly, M. and Koné, M. (2021) Bladder Cancer: Epidemiological, Clinical and Histopathological Aspects at the University Hospital Point G, Mali. Open Journal of Urology, 11, 343-350.

https://doi.org/10.4236/oju.2021.1110033

Received: August 9, 2021

Accepted: October 17, 2021

Published: October 20, 2021

Copyright (อ 2021 by author(s) and Scientific Research Publishing Inc. This work is licensed under the Creative Commons Attribution International License (CC BY 4.0).

http://creativecommons.org/licenses/by/4.0/ (c) (i) Open Access

\begin{abstract}
Introduction: Bladder cancer is a new tissue formation most often of urothelial origin with potential for local, locoregional and distant invasion. Among its risk factors, urinary bilharzia is endemic in our study area. The aim of our study was to present the epidemiological, clinical and histopathological aspects of bladder cancer in our department. Patients and method: This was a descriptive cross-sectional study over a 12-month period from January 1 to December 31,2019. The study took place in the urology department of the university hospital Point "G". It included all patients hospitalized for bladder cancer. The epidemiological, clinical and histopathological characteristics have been sought and described. Results: A total of 74 patients were included in the study. Bladder cancer was the leading cause of cancer, accounting for $57.9 \%$ of all urological cancers. The mean age of the patients was $52.8 \pm 16.25$ years. A slight male predominance was observed with a sex-ratio of 1.2. Housewives were the most represented with $43.2 \%$ followed by farmers with $24.3 \%$. Hematuria was the reason for consultation in $87.8 \%$ cases. The main risk factors found were urinary schistosomiasis (48.6\%) and smoking (31.1\%). These two factors were associated in $23.0 \%$ of cases. At diagnosis, $85.7 \%$ of patients were classified as T3 or T4 stage. Squamous cell carcinoma with $58.2 \%$ was the most common histological type followed by
\end{abstract}


urothelial carcinoma in $26.0 \%$ of cases. Conclusion: Bladder cancer is very common of cancer in hospitalized patients in our department. Diagnosis is more often made at an advanced stage. The most common histological type is squamous cell carcinoma.

\section{Keywords}

Bladder Cancer, Epidemiology, Clinic, Histopathology

\section{Introduction}

Bladder cancer is a new tissue formation most often of urothelial origin with potential for local, locoregional and distant invasion. It is most often a tumor invading the bladder muscle. It is sometimes a tumor which does not directly infiltrate the bladder muscle but given that it is of high histological grade, this could presage an evolution towards the mode infiltrating the bladder muscle. This ambiguity in evolution will lead us to speak more often of a bladder tumor. Bladder cancer with 16,390 deaths in 2016 is one of the deadliest genitourinary tumors in the USA [1]. In Europe, it is the second urological cancer after prostate cancer [2]. In Mali, it is the $4^{\text {th }}$ most diagnosed cancer and is responsible for $4.0 \%$ of all cancer deaths [2]. Smoking and occupational exposure are the main risk factors [3]. In Africa, in bilharzia endemic areas, there is a histological type, squamous cell carcinoma, characterized by a high risk of local progression, recurrence and reduced sensitivity to chemotherapy and radiotherapy [4] [5]. This specificity requires the discovery of the tumor at an early stage for effective management, because no lifesaving therapy is effective in late stages. The low availability of endoscopic devices, especially in peripheral areas, the high cost of care compared to the income level of the most affected populations and the delay in consultation due to the similarity of signs between urinary schistosomiasis and bladder cancer, make it difficult to discover the pathology at the early stage. As a result, bladder cancer represents a real challenge for urologists working in bilharzia endemic areas of sub-Saharan African countries where it is characterized by a high specific mortality rate. Thus, with 5.2 deaths per 100,000 inhabitants, Mali is ranked $5^{\text {th }}$ in the world for the highest age-standardized mortality rate of this condition [6]. The aim of our study was to present the epidemiological, clinical and histopathological aspects of bladder cancer in our department.

\section{Patients and Method}

This was a descriptive cross-sectional study over a 12-month period from January 1 to December 31,2019. The study took place in the urology department of the Point "G" University Hospital, Mali. It included all hospitalized patients for bladder cancer. An investigation sheet comprising epidemiological data (age, sex, profession, level of education, risk factors), clinical data (consultation time, results of the physical examination, TNM 2009 classification) and histopatho- 
logical data were recorded for each patient. All of this information was collected from the medical records of the patients. Data were analyzed using SPSS software.

\section{Results}

A total of 74 patients were included in the study. Bladder cancer with $10.6 \%$ represented the $4^{\text {th }}$ reason for hospitalization after benign prostatic hyperplasia, urolithiasis and urogenital fistulas. However, it occupied the $1^{\text {st }}$ rank of urological cancers with $57.9 \%$ ahead of prostate, cancer $26.5 \%$ and kidney cancer $14.8 \%$. The mean age of the patients was $52.8 \pm 16.2$ years with ranges of 11 to 89 years. There was a slight male predominance with a sex ratio of 1.2. Housewives represented $43.2 \%$ of patients. The main risk factors found were urinary schistosomiasis, $48.6 \%$ and smoking, $31.1 \%$. These two factors were associated in $23.0 \%$ of cases. The epidemiological aspects are summarized in Table 1.

Table 1. Epidemiological aspects.

\begin{tabular}{|c|c|c|}
\hline Variables & Frequency & Percentage \\
\hline \multicolumn{3}{|l|}{ Sex } \\
\hline Man & 40 & $54.1 \%$ \\
\hline Woman & 34 & $45.9 \%$ \\
\hline \multicolumn{3}{|l|}{ Age (year) } \\
\hline Less than 30 & 7 & $9.5 \%$ \\
\hline $30-50$ & 22 & $29.7 \%$ \\
\hline $51-70$ & 40 & $54.0 \%$ \\
\hline Over 70 & 5 & $6.8 \%$ \\
\hline Total & 74 & 100 \\
\hline \multicolumn{3}{|l|}{ Profession } \\
\hline Housewife & 32 & $43.2 \%$ \\
\hline Farmer & 18 & $24.3 \%$ \\
\hline Civil servant & 11 & $14.9 \%$ \\
\hline Other & 13 & $17.6 \%$ \\
\hline Total & 74 & 100 \\
\hline \multicolumn{3}{|l|}{ Educational level } \\
\hline Primary & 19 & $25.7 \%$ \\
\hline Secondary & 5 & $6.7 \%$ \\
\hline University & 3 & $4.1 \%$ \\
\hline Illiterate & 47 & $63.5 \%$ \\
\hline Total & 74 & 100 \\
\hline \multicolumn{3}{|l|}{ Risk factors found } \\
\hline Bilharzia & 19 & 25.7 \\
\hline Tobacco & 6 & 8.1 \\
\hline Bilharzia and Tobacco & 17 & 23.0 \\
\hline None & 32 & 43.2 \\
\hline Total & 74 & 100 \\
\hline
\end{tabular}


The consultation time was over 1 year in $59.4 \%$. Hematuria was the main reason for consultation with $87.8 \%(n=65)$. It was associated with lower urinary tract disorders in $55.4 \%(\mathrm{n}=41)$ of cases. Signs of advanced disease were found in $66.2 \%$ of cases, consisting of the pelvic shield, $36.5 \%$ and the hypogastric mass, $29.7 \%$. At diagnosis, $85.4 \%$ of patients were classified as T3 or T4. Clinical aspects are presented in Table 2.

Urinary cytology was positive, revealing carcinoma in $63.0 \%$ of patients. The histological type obtained after biopsy during cystoscopy or after trans urethral resection of the bladder was dominated by squamous cell carcinoma which constituted $58.2 \%$ of cases. In Figure 1 are illustrated the different histological types.

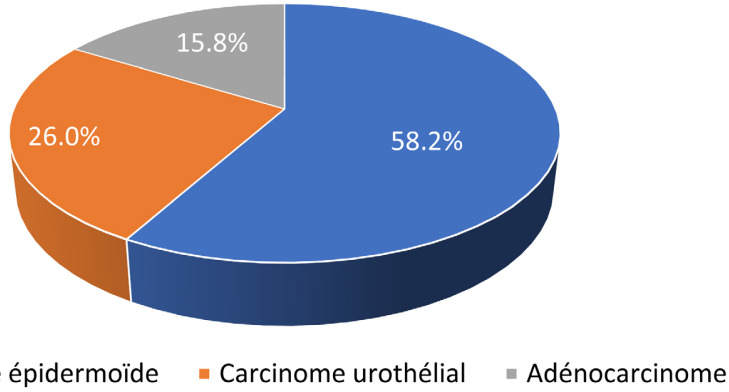

- Carcinome épidermoïde = Carcinome urothélial ॥ Adénocarcinome

Figure 1. Histological types.

Table 2. Clinical aspects.

\begin{tabular}{|c|c|c|}
\hline Variables & Frequency & Percentage \\
\hline \multicolumn{3}{|c|}{ Consultation time (month) } \\
\hline Less than 6 & 15 & 20.3 \\
\hline $6-12$ & 15 & 20.3 \\
\hline $13-18$ & 24 & 32.4 \\
\hline More than 18 & 20 & 27.0 \\
\hline Total & 74 & 100 \\
\hline \multicolumn{3}{|c|}{ Result of physical examination } \\
\hline Pelvic shielding & 27 & 36.5 \\
\hline Hypogastric mass & 22 & 29.7 \\
\hline Bladder globe & 2 & 2.7 \\
\hline Normal & 23 & 31.1 \\
\hline Total & 74 & 100 \\
\hline \multicolumn{3}{|l|}{ Classification } \\
\hline $\mathrm{T} 2$ & 11 & 14.86 \\
\hline T3 & 18 & 24.32 \\
\hline $\mathrm{T} 4$ & 45 & 60.82 \\
\hline Total & 74 & 100 \\
\hline
\end{tabular}




\section{Discussion}

Bladder cancer represented $10.6 \%$ of the activities of our hospitalization department. It was the most frequent urological cancer with $57.9 \%$, ahead of prostate cancer, $26.5 \%$. This finding is in contrast with other from countries in the same geographic area. Thus, in Benin, with a frequency of $28.5 \%$, it came largely after prostate cancer, $69.0 \%$ [7]. In Senegal, the frequency of bladder cancer has fallen sharply compared to other urological tumors, dropping from $86.9 \%$ to $18.0 \%$ [8] where prostate cancer is predominant. This change in trend is believed to be due to an improvement in prostate cancer screening tools in recent years in the countries of Sub-Saharan Africa (SSA). In Mali, the high frequency of bladder cancer is more likely to be explained by a more severe endemic bilharzia (one in four people is affected) and more widespread with poor epidemiological control [9]. Both sexes were affected with almost the same prevalence in our study with a sex-ratio of 1.17 . About $45.0 \%$ of the men were farmers, while $94.1 \%$ of the women were housewives. Men and women shared the same risk of exposure to bilharzia in rural areas. The slightly higher prevalence in men could be explained by other factors such as smoking. This phenomenon was until then quite marginal among women in Mali unlike the populations of countries in Europe and America.

The regions in which our patients most often come from were areas with high Bilharzia endemicity (Bamako, Koulikoro, Ségou and Kayes) due to the presence of numerous rivers and hydrological dams [10]. The populations there quite often practice fun aquatic activities, especially in childhood and or at work. Bladder tumors in Sub-Saharan Africa are most often related to a history of bilharzia infestation [11]. On average, a period of about 30 years separates the first bilharzial infestation and subsequent bladder cancer [12]. The first infestation occurring most often in childhood and would be responsible for the early onset of bladder cancer in bilharzia endemic areas, while in Europe and America, the age of onset is between sixth and seventh decade [1] [2]. In our study, urinary schistosomiasis was the risk factor most frequently associated with bladder cancer (48.7\%). In $43.2 \%$ no factor was found, an old bilharzian involvement cannot be ruled out in these cases. Hematuria, which is the main sign sought to determine the history of urinary schistosomiasis, is only present in $50 \%$ of cases of Shistosoma hematobium [9].

Bilharzia was associated with $29.0 \%$ to $85.0 \%$ of squamous bladder cancers and $10 \%$ of transitional cell carcinomas in SSA [11]. Bilharzia and smoking both increase the risk of squamous cell cancer and urothelial bladder cancer [13], in our study this association was found in $23.0 \%$ of cases.

Our study revealed a great delay in consultation of patients suffering from bladder cancer. In $59.4 \%$ of cases, the consultation in a specialized environment was carried out more than 12 months after the onset of symptoms. This delay in consultation could be mainly due to the trivialization of hematuria in a context of endemic bilharzia. Thus in the majority of cases, $66.2 \%$, the tumor was clinically evident in our patients by palpation of a hypogastric mass or the presence 
of pelvic shielding on rectal examination. According to a study, $27.0 \%$ of squamous cell type bladder cancers consult at an inoperable stage in Africa [11]. In our study, $60.2 \%$ of tumors were diagnosed at the inoperable T4 stage, in agreement with the high mortality rate linked to bladder cancer recorded in Mali [6].

Confirming previous results in SSA [8] [11] [14], our study found a predominance of squamous cell carcinoma with $58.2 \%$ of cases, followed by urothelial carcinoma, 26.0\%. Shistosoma haematobium infection was recognized in 1994 by the International Agency for Research on Cancer (IARC) and confirmed in 2012 as a class A carcinogen [15] [16]. In Egypt, a decrease in squamous cell forms in favor of urothelial forms with the decline of Shistosoma haematobium infection is evidence of the role of urinary schistosomiasis in the development of bladder squamous cell carcinoma [17] [18]. In Nigeria, depending on the study populations, the prevalence of squamous cell carcinoma ranges from $39 \%$ to $66 \%$ [11]. In Mali, in a region different from the site of our study, with high bilharzia endemicity where $73.5 \%$ of patients had a history of urinary schistosomiasis [19], the prevalence of squamous cell carcinoma was $82.1 \%$ [19]. This large difference between regions is mainly linked to the variation in the prevalence of urinary schistosomiasis.

Due to the late discovery of the pathology, only $14.86 \%$ of patients were able to benefit from a curative treatment. This treatment consisted of a total cystectomy with bladder replacement. For the rest of the patients, it was a palliative treatment consisting of transurethral resections of the bladder, urinary diversions, analgesics. Radiotherapy and chemotherapy were not part of our medical means because of the high cost for our patients on the one hand, the general condition of the patients sometimes very altered and the histological type often not very sensitive to radiotherapy and chemotherapy on the other hand.

This study poses two essential problems: Firstly, the delay in consultation due to the presence of the bilharzian endemic which leads to the appearance of histological type with little chemo and radio sensitivity and secondly the weakness of the technical platform by the unavailability and financial inaccessibility of therapeutic means for the moment poorly adapted to the histological type present. La résolution de ce paradoxe passe par la lutte contre la bilharziose qui permettra de diminuer le carcinome épidermoïde et de rendre accessible les moyens thérapeutiques pour les autres types histologiques en attendant l'inversion des proportions histologiques comme cela s'est vue en Egypte [17] [18].

The limitation of this study is that it is unicentric. Indeed, this center is a tertiary center that receives serious cases from other structures. This selection bias could explain the large proportion of terminal pathologies. A multicenter study could provide a more comprehensive picture of the bladder cancer situation in the country.

\section{Conclusion}

Bladder cancer is very common in patients hospitalized in our department. They are characterized by a delay in consultation responsible for a discovery of the 
pathology at an advanced stage. Squamous cell carcinoma is the most frequent histological type, favored by endemic bilharzia, responsible for the delay in consultation by trivialization of hematuria. Effective control measures against urinary schistosomiasis should help reduce the prevalence of bladder cancer.

\section{Conflicts of Interest}

None.

\section{Funding Source}

None.

\section{References}

[1] American Cancer Society (2016) Cancer Facts \& Figures 2016. American Cancer Society, Atlanta.

https://www.cancer.org/research/cancer-facts-statistics/all-cancer-facts-figures/canc er-facts-figures-2016.html

[2] Ferlay, J., Soerjomataram, I., Dikshit, R., Eser, S., Mathers, C., Rebelo, M., Parkin, D. M., Forman, D. and Bray, F. (2015) Cancer Incidence and Mortality Worldwide: Sources, Methods and Major Patterns in GLOBOCAN 2012. International Journal of Cancer, 136, E359-E386. https://doi.org/10.1002/ijc.29210

[3] Stewart, B.W. and Wild, C.P. (Eds.) (2014) World Cancer Report 2014. International Agency for Research on Cancer, Lyon, 444-452.

https://publications.iarc.fr/Non-Series-Publications/World-Cancer-Reports/WorldCancer-Report-2014

[4] Pons, F., Orsola, A., Morote, J. and Bellmunt, J. (2011) Variant Forms of Bladder Cancer: Basic Considerations on Treatment Approaches. Current Oncology Reports, 13, 216-221. https://doi.org/10.1007/s11912-011-0161-4

[5] Chalasani, V., Chin, J.L. and Izawa, J.I. (2009) Histologic Variants of Urothelial Bladder Cancer and Nonurothelial Histology in Bladder Cancer. Canadian Urological Association Journal, 3, S193-S198. https://doi.org/10.5489/cuaj.1195

[6] Mahdavifar, N., Ghoncheh, M., Pakzad, R., Momenimovahed, Z. and Salehiniya, H. (2016) Epidemiology, Incidence and Mortality of Bladder Cancer and Their Relationship with the Development Index in the World. Asian Pacific Journal of Cancer Prevention, 17, 381-386. https://doi.org/10.7314/APJCP.2016.17.1.381

[7] Ouattara, A., Hodonou, R., Avakoudjo, J., Cisse, D., Zango, B., Gandaho, I., et al. (2012) Épidémiologie des cancers urologiques au Centre national hospitalier universitaire Hubert Koutoukou Maga Cotonou, Bénin. Analyse d'une série hospitalière de 158 cas. Progrès en Urologie, 22, 261-265.

https://doi.org/10.1016/j.purol.2011.12.003

[8] Diao, B., Amath, T., Fall, B., Fall, P.A., Diémé, M.J., Steevy, N.N., Ndoye, A.K., Ba, M., Mendes, V. and Diagne, B.A. (2008) Les cancers de vessie au Sénégal: Particularités épidémiologiques, cliniques et histologiques [Bladder Cancers in Senegal: Epidemiological, Clinical and Histological Features]. Progres en urologie, 18, 445-448. https://doi.org/10.1016/j.purol.2008.04.016

[9] Chippaux, J.-P. (éditeur) (2000) La lutte contre les schistosomoses en Afrique de l'Ouest. Éditions IRD, Paris, 290 p.

[10] Doumengue, J.-P. (1987) Atlas de la répartition mondiale des schistosomiases. Presses 
universitaires de Bordeaux, Talence.

[11] Bowa, K., Mulele, C., Kachimba, J., Manda, E., Mapulanga, V. and Mukosai, S. (2018) A Review of Bladder Cancer in Sub-Saharan Africa: A Different Disease, with a Distinct Presentation, Assessment, and Treatment. Annals of African Medicine, 17, 99-105. https://doi.org/10.4103/aam.aam $48 \quad 17$

[12] Shokeir, A.A. (2004) Squamous Cell Carcinoma of the Bladder: Pathology, Diagnosis and Treatment. BJU International, 93, 216-220. https://doi.org/10.1111/j.1464-410X.2004.04588.x

[13] Zheng, Y.L., Amr, S., Saleh, D.A., Dash, C., Ezzat, S., Mikhail, N.N., Gouda, I., Loay, I., Hifnawy, T., Abdel-Hamid, M., Khaled, H., Wolpert, B., Abdel-Aziz, M.A. and Loffredo, C.A. (2012) Urinary Bladder Cancer Risk Factors in Egypt: A Multicenter Case-Control Study. Cancer Epidemiology, Biomarkers \& Prevention, 21, 537-546. https://doi.org/10.1158/1055-9965.EPI-11-0589

[14] Darré, T., Amégbor, K., Kpatcha, M., Tengue, K., Sonhaye, L., Doh, K., et al. (2014) Cancers urologiques au Togo: Profil histoépidémiologique à propos de 678 cas. African Journal of Cancer, 6, 27-31. https://doi.org/10.1007/s12558-013-0296-3

[15] IARC (International Agency for Research on Cancer) (1994) Monographs on the Evaluation of Carcinogenic Risks to Humans Volume 61 Schistosomes, Liver Flukes and Helicobacter pylori. International Agency for Research on Cancer, 279 p.

[16] IARC (International Agency for Research on Cancer) (2012) Monographs on the Evaluation of Carcinogenic Risks to Humans. Biological Agents. Volume 100B: A Review of Human Carcinogens. International Agency for Research on Cancer, 499 p.

[17] Salem, H.K. and Mahfouz, S. (2012) Changing Patterns (Age, Incidence, and Pathologic Types) of Schistosoma-Associated Bladder Cancer in Egypt in the Past Decade. Urology, 79, 379-383. https://doi.org/10.1016/j.urology.2011.08.072

[18] Gouda, I., Mokhtar, N., Bilal, D., El-Bolkainy, T. and El-Bolkainy, N.M. (2007) Bilharziasis and Bladder Cancer: A Time Trend Analysis of 9843 Patients. Journal of the Egyptian National Cancer Institute, 19, 158-162.

[19] Cissé, D., Berthé, H.J.G., Diarra, A., Coulibaly, M.T., Diallo, M.S., Kassogué, A., Thiam, D., Traore, A., Koné, M. and Guindo, O. (2020) Les Tumeurs de Vessie à l'Hopital Somine Dolo de Mopti. Health Sciences and Disease, 21, 69-74. https://www.hsd-fmsb.org/index.php/hsd/article/view/2309/pdf 1079 